\title{
https://doi.org/10.46813/2021-133-132 \\ STUDY OF PURIFICATION PROCESSES OF SOIL CONTAMINATED WITH URANYL NITRATE
}

\author{
Kh.F. Mammadov, H.N. Shiraliyeva, E.I. Mehtiyev, U.S. Aliyeva-Jabbarly, E.I. Guliyev, \\ N.A. Mirzayev, A.H. Huseynova \\ Institute of Radiation Problems, Azerbaijan National Academy of Sciences, Baku, Azerbaijan \\ E-mail: radiasiya@irp.science.az;xagani06@mail.ru
}

The extraction of uranyl nitrate contaminated soil with weak solutions of nitric and hydrochloric acid, caustic sodium and subsequent washing of soil residues with distilled water leads to a more than tenfold decrease in the content of uranium isotopes $\left(\mathrm{U}^{238}, \mathrm{U}^{235}, \mathrm{U}^{234}\right.$, and $\left.\mathrm{U}^{236}\right)$ in the soil. At the same time, there is a decrease in the content of natural radionuclides $\left(\mathrm{Na}^{22}, \mathrm{~K}^{40}, \mathrm{Zn}^{65}, \mathrm{Sn}^{113}, \mathrm{Sn}^{126}\right)$ in the extracted soil samples. An increase in their content in the extract of the analyzed soil sample corresponds to a decrease in their content in the residue of the extracted soil sample. The combined extraction with weak solutions of these acids and alkalis leads to the enrichment of the soil with nitrates and chlorine-containing compounds of non-radioactive metals.

PACS: 89.60.Ec

\section{INTRODUCTION}

Some areas of the soil of some territories of the country have been contaminated as a result of the implementation of traditional oil production projects and the exploitation of numerous deposits of minerals. Oil wastes and radioactive elements associated with oil production, which have been accumulating for decades on the territories of oil and gas production enterprises predominate among anthropogenic pollutants. Emissions of effluents from physical treatment (washing) of oil with purified water led to the accumulation of radionuclides in the surrounding areas around oil refineries. Huge areas contaminated with heavy metals and radionuclides have arisen at the exploitation of raw material deposits of cement and brick production. Such areas have arisen on the coastal areas of large rivers, systematically polluted by wastes of chemical production, metal mining and processing [1 - 3].

Previously, we studied the distribution of natural radionuclides in soil samples and the processes of cleaning these samples using methods of chemical soil treatment, and we studied the processes of separating uranium isotopes from water using different adsorbents [4, 5].

The development of methods for cleaning contaminated soil from radioactive components in order to ensure radiation safety is one of the urgent problems of radiochemistry. The possibilities of cleaning soil contaminated with uranyl nitrate and uranium isotopes have been studied in the present work.

\section{EXPERIMENTAL PART}

Measurements of the radioactive background in a local area contaminated with chemical waste (residues of expired chemical reagents) were carried out using an InSpector 1000 (Canberra) radiometer equipped with a gamma radiation detector and a Radiagem (Canberra) radiometer equipped with gamma, alpha and beta radiation detectors. Atomic absorption (AA-6800, Shimadzu) and X-ray fluorescence spectroscopy (Expert-3L and $\mathrm{XRF}$ ) and analyzes on a gamma spectrometer equipped with a "Genie 2000" spectroscopic system and a germa- nium detector of high purity and on alpha and beta spectrometers (Canberra) were carried out to identify and evaluate the efficiency of the release of radioactive elements from soil samples. Certified point radioactive sources and standard solutions of uranium isotopes with different activity were used for the calibration. The decrease in the activity of the point source according to the half-life of a particular isotope was taken into account for previously certified weak point sources.

Purification of uranyl nitrate contaminated (in the International Classification of Goods and Services / ICGS / in class No. 1 is registered as a product category called "uranium nitrate") soil samples were carried out by their extraction with weak aqueous solutions of caustic potassium, nitric acid, mixture / 1:2 / nitric and hydrochloric acids. Some samples of the extracted soil were subsequently washed / extracted / also with distilled water. The energy spectra of ionizing rays were recorded both from the remaining residue of the extract after its evaporation, and from the residue of the extracted soil after each stage of the extraction.

\section{DISCUSSION OF THE RESULTS}

Previous analyzes showed that the activity of isotopes $\mathrm{Na}^{22}, \mathrm{~K}^{40}, \mathrm{Zn}^{65}, \mathrm{Sn}^{113}, \mathrm{Sn}^{126}$ in soil of the Shirvan region was $2.7,2.5,0.16,0.07$ and $0.3 \mathrm{~Bq} / \mathrm{kg}$, respectively. $40 \ldots 96 \%$ of the indicated radionuclides $(15 . .40 \%$ of $\mathrm{K}^{40}$ ) were extracted from the soil with the extraction by the described above methods [2 - 4]. The background values of radioactive gamma and beta radiation in the Shirvan region were $0.12 \cdot 10^{-6} \mathrm{~Sv} / \mathrm{h}$ and $1.22 \mathrm{~Bq} / \mathrm{cm}^{2}$, respectively.

Soil samples taken from a local area of soil contaminated with chemical waste (residues of expired chemical reagents, mainly uranyl nitrate / $\mathrm{UO}_{2}\left(\mathrm{NO}_{3}\right)_{2} /$ produced in the forties of the last century) were analyzed in this work. The conclusion about the presence of this substance in soil samples was made on the basis of acts of write-off of chemical reagents and generalization of the analysis results (the appearance of cornflower blue coloration in reddish-yellow aqueous extracts of this soil when diphenylamine crystals are added to them and the spectra of gamma, alpha and beta spectrometric ana- 
lyzes). This contaminated local soil area created a relatively high background of gamma and beta radiation, values that were $0.60 \cdot 10^{-6} \mathrm{~Sv} / \mathrm{h}$ and $3.72 \mathrm{~Bq}_{\mathrm{eq}} / \mathrm{cm}^{2}$, respectively. Alpha radiation was also recorded by measurements carried out directly on the surface of this soil area using the "Radiagem" radiometer.

The identification of the isotope in the contaminated soil was carried out by the value of the energy of the rays emitted by it. The energies of gamma quanta emitted by $\mathrm{U}^{235}$ were 186 and $144 \mathrm{keV}$, the energies of gamma quanta irradiated by $\mathrm{U}^{234}, \mathrm{U}^{236}$, and $\mathrm{U}^{238}$ were 53,113 , and $48 \mathrm{keV}$, respectively. The most intense in height are the peaks corresponding to the energy of gamma quanta irradiated by $\mathrm{U}^{238}$, somewhat smaller in height, the peaks corresponding to the energy of gamma quanta irradiated by $\mathrm{U}^{235}$, and for isotopes $\mathrm{U}^{234}$ and $\mathrm{U}^{236}$, the intensity of the peaks corresponding to the energy of gamma quanta from these isotopes is many times low. Duplicate measurements were performed by alpha and beta spectroscopy. The alpha-ray energies emitted by $\mathrm{U}^{235}$ were 4396 , and $4365 \mathrm{keV}$, the alpha-ray energies emitted by $\mathrm{U}^{234}, \mathrm{U}^{236}$ and $\mathrm{U}^{238}$ were 4775,4494 and $4196 \mathrm{keV}$, respectively.

The height of the spectral peak corresponds to the number of fixed energy beams emitted by the isotope in a given time. The activity of the isotope in the soil extract was determined by comparing the height of its spectroscopic peak with the height of the spectroscopic peak of the same isotope in a point source or in a standard solution (with a fixed activity value in the certificate).

The total mass of the contaminated soil was dried up. These mass divided to parts with mass of each

$200 \mathrm{~g}$. The spectrometric analyzes carried out showed that in the soil contaminated with uranyl nitrate wastesthe ratio of the total content of compounds of the isotopes $\mathrm{U}^{238}, \mathrm{U}^{235}$ to the total content of isotopes $\mathrm{U}^{234}$ and $\mathrm{U}^{236}$ is approximately 99: 1 . The activity of uranium isotopes in all prepared soil samples (weighing 200 grams) was $30 \mathrm{~Bq}$ for $\mathrm{U}^{238}, 10 \mathrm{~Bq}$ for $\mathrm{U}^{235}$, and less than $1 \mathrm{~Bq}$ for isotopes $\mathrm{U}^{234}$ and $\mathrm{U}^{236}$. The presence of the isotopes $\mathrm{U}^{238}, \mathrm{U}^{235}, \mathrm{U}^{234}$ and $\mathrm{U}^{236}$ were detected at different ratios in trace amounts of the yellowish salt of uranyl nitrate, found on the bottom of glass jars of expired chemical reagents produced in the forties of the last century. The change in the ratio of these isotopes apparently occurred due to the modification of the composition of the salt, buried in the soil for more than half a century.

Samples of soils contaminated with uranyl nitrate were extracted with dilute solutions of nitric acid in distilled water, aqueous solutions of sodium hydroxide and with the mixture of nitric acid and hydrochloric acid (1:2). The remaining part of the soil was re-extracted with distilled water as well, after transferring to a glass flask and filtering the extract. The activity of uranium isotopes in the filtered and partially evaporated extract, as well as in the soil residue, was determined each time.

The degree of extraction of uranium isotopes from the soil sample was estimated by studying the decrease in the activity of uranium isotopes in the soil and the increase in their activity in the extract. The results of the extraction of uranylnitrate from samples of contaminated soil, weighing $200 \mathrm{~g}$, with diluted aqueous solutions of acids and alkalis, are shown in Tables 1 - 3 .

\section{Table 1}

Decrease in the content (activity) of uranium isotopes in a soil sample (200 g) upon extraction with sodium hydroxide solutions in distilled water

\begin{tabular}{|l|c|c|c|}
\hline \multirow{2}{*}{$\begin{array}{l}\text { Soil sample studied by gamma spectroscopy at different stages } \\
\text { of experiments }\end{array}$} & \multicolumn{3}{|c|}{ Activity of uranium isotopes, Bq } \\
\cline { 2 - 4 } & $\mathrm{U}^{238}$ & $\mathrm{U}^{235}$ & $\mathrm{U}^{234}, \mathrm{U}^{236}$ \\
\hline Initial soil sample & 30 & 10 & 1 \\
\hline $\begin{array}{l}\text { In the soil residue after extraction with 0.2 M sodium hydroxide } \\
\text { solution }\end{array}$ & 28 & 9 & 0.8 \\
\hline $\begin{array}{l}\text { In the soil residue after extraction with 0.5 M sodium hydroxide } \\
\text { solution }\end{array}$ & 26 & 8 & 0.6 \\
\hline $\begin{array}{l}\text { In the soil residue after extraction with 1.0 M sodium hydroxide } \\
\text { solution }\end{array}$ & 24 & 7 & 0.4 \\
\hline $\begin{array}{l}\text { In the soil residue after extraction with 2.0 M sodium hydroxide } \\
\text { solution }\end{array}$ & 18 & 5 & 0.1 \\
\hline
\end{tabular}

Decrease in the content (activity) of uranium isotopes in a soil sample (200 g) upon extraction

Table 2 with solutions of nitric acid in distilled water

\begin{tabular}{|c|c|c|c|}
\hline \multirow{2}{*}{$\begin{array}{l}\text { Soil sample studied by gamma spectroscopy at different stages } \\
\text { of experiments }\end{array}$} & \multicolumn{3}{|c|}{ Activity of uranium isotopes, $\mathrm{Bq}$} \\
\hline & $\mathrm{U}^{238}$ & $\mathrm{U}^{235}$ & $\mathrm{U}^{234}, \mathrm{U}^{236}$ \\
\hline Initial soil sample & 30 & 10 & 1 \\
\hline In the soil residue after extraction with $0.2 \mathrm{M}$ nitric acid solution & 27 & 9 & 0.7 \\
\hline In the soil residue after extraction with $0.5 \mathrm{M}$ nitric acid solution & 24 & 8 & 0.5 \\
\hline In the soil residue after extraction with $1.0 \mathrm{M}$ nitric acid & 20 & 6.5 & 0.2 \\
\hline In the soil residue after extraction with $2.0 \mathrm{M}$ nitric acid & 13 & 4 & 0.05 \\
\hline
\end{tabular}


Decrease in the content (activity) of uranium isotopes in a soil sample (200 g) upon extraction with solutions of mixtures of nitric and hydrochloric acids in distilled water

\begin{tabular}{|c|c|c|c|}
\hline \multirow{2}{*}{$\begin{array}{l}\text { Soil sample studied by gamma spectroscopy at different stages } \\
\text { of experiments }\end{array}$} & \multicolumn{3}{|c|}{ Activity of uranium isotopes, $\mathrm{Bq}$} \\
\hline & $\mathrm{U}^{238}$ & $\mathrm{U}^{235}$ & $\mathrm{U}^{234}, \mathrm{U}^{236}$ \\
\hline Initial soil sample & 30 & 10 & 1 \\
\hline $\begin{array}{l}\text { Soil residue after extraction with a solution of a mixture of } 0.2 \mathrm{M} \\
\text { nitric and } 0.4 \mathrm{M} \text { hydrochloric acids }\end{array}$ & 24 & 8 & 0.6 \\
\hline $\begin{array}{l}\text { Soil residue after extraction with a solution of a mixture of } 0.5 \mathrm{M} \\
\text { nitric and } 1.0 \mathrm{M} \text { hydrochloric acids }\end{array}$ & 20 & 6.5 & 0.3 \\
\hline $\begin{array}{l}\text { The rest of the soil after extraction with a solution of a mixture } \\
\text { of } 1.0 \mathrm{M} \text { nitric and } 2.0 \mathrm{M} \text { hydrochloric acids; } \\
\text { - followed by extraction with } 1.0 \mathrm{M} \text { sodium hydroxide solution }\end{array}$ & $\begin{array}{c}13 \\
8\end{array}$ & $\begin{array}{c}4 \\
1.5\end{array}$ & $\begin{array}{c}0.1 \\
0.05\end{array}$ \\
\hline $\begin{array}{l}\text { The rest of the soil after extraction with a solution of a mixture } \\
\text { of } 2.0 \mathrm{M} \text { nitric and } 4.0 \mathrm{M} \text { hydrochloric acids; } \\
\text { - followed by extraction with } 1 \text { liter. distilled water }\end{array}$ & $\begin{array}{l}3 \\
2\end{array}$ & $\begin{array}{c}1 \\
0.5\end{array}$ & $\begin{array}{l}0.04 \\
0.02\end{array}$ \\
\hline
\end{tabular}

The results of the performed gamma spectroscopic analyzes show an increase in the content (activity) of uranium isotopes $\left(\mathrm{U}^{238}, \mathrm{U}^{235}, \mathrm{U}^{234}\right.$ and $\left.\mathrm{U}^{236}\right)$ in evaporated extracts of the analyzed soil samples with an increase in the concentration of used acidic and alkaline solutions. An increase in the content (activity) of uranium isotopes in the extracts corresponds to a decrease in the content of isotopes in the remains of the extracted soil samples, within a confidence interval of errors of $+5 \%$.

As can be seen from Table 3, the results of the combined extraction of contaminated soil with acids, alkali and water lead to a significant/approximately tenfold/ decrease in the content of uranium isotopes in the soil. In addition to a decrease in the content of uranium isotopes in the extracted soil samples, a decrease in the content of other natural radionuclides is observed, also. At the same time, the results of reducing the content of natural radionuclides $\left(\mathrm{Na}^{22}, \mathrm{~K}^{40}, \mathrm{Zn}^{65}, \mathrm{Sn}^{113}, \mathrm{Sn}^{126}\right)$ correspond to the values of reducing their content (from 30 to $90 \%$ ) when extracting identical soil samples, but not contaminated with uranium isotopes [2 - 4].

The combined extraction with acids and alkali reduces the values of gamma and beta radiation from the mass of the contaminated soil to the values of the soil not contaminated with uranium nitrate $\left(0.1 \cdot 10^{-6} \mathrm{~Sv} / \mathrm{h}\right.$ and $1.0 \mathrm{~Bq} / \mathrm{cm}^{2}$, respectively). It is observed also the enrichment of the soil with chlorides and nitrates formed as a result of the neutralization reaction.

\section{CONCLUSIONS}

The results of the combined extraction of contaminated soil with weak solutions of acid, caustic alkali and the subsequent washing of the soil residue with water leads to a more than tenfold decrease in the content of uranium isotopes in the soil. An increase in the content of uranium isotopes in the extracts of the analyzed soil samples corresponds to a decrease in the content of these isotopes in the remains of the extracted soil samples. The comparative analysis of the values of the decrease in the content of natural radionuclides in the soil contaminated with uranyle nitrate corresponds to the values of the decrease in their content in the identical soil, but not contaminated with uranium isotopes. Extraction with weak aqueous solutions of nitric acid and caustic sodium leads to the enrichment of chlorides and nitrates formed during the combined extraction of soil contaminated with uranyle nitrate.

\section{REFERENCES}

1. D.S. Orlov, L.K. Sadovnikova, N.I. Sukhanova. Chemistry of soil. M.: "Higher School", 2005, p. 558.

2. Kh.F. Mammadov, A.M. Gulamirov, R.G. Garibov, et al. // Azerbaijan Chem. J. 2018, № 4, p. 68.

3. Kh.F. Mammadov, R.G. Garibov, H.N. Shiraliyeva, et al. // J. Radiat. Researches. 2017, v. 4, № 2, p. 72.

4. Kh.F. Mammadov, H.N. Shiraliyeva // J. Radiat. Researches. 2020, v. 7, № 2, p. 62.

5. Kh.F. Mammadov, H.N. Shiraliyeva, M.N. Mirzayev, et al. // J. Radiat. Research. 2018. v. 5, № 2, p. 328. 


\section{ИЗУЧЕНИЕ ПРОЦЕССОВ ОЧИСТКИ ОБРАЗЦОВ ПОЧВЫ, ЗАГРЯЗНЕННЫХ НИТРАТОМ УРАНИЛА}

Х.Ф. Маммадов, Х.Н. Ширалиева, Э.И. Мехтиев, У.С. Алиева-Джаббарлы, Э.И. Кулиев, Н.А. Мирзаев, А.Г. Гусейнова

Комбинированное экстрагирование загрязненной нитратом уранила почвы слабыми растворами азотной и соляной кислоты, едкого натрия и последующее промывание остатков почвы дистиллированной водой приводят к более десятикратному снижению содержания изотопов урана $\left(\mathrm{U}^{238}, \mathrm{U}^{235}, \mathrm{U}^{234}\right.$ и $\left.\mathrm{U}^{236}\right)$ в почве. При этом наблюдается снижение также содержания природных радионуклидов $\left(\mathrm{Na}^{22}, \mathrm{~K}^{40}, \mathrm{Zn}^{65}, \mathrm{Sn}^{113}, \mathrm{Sn}^{126}\right)$ в экстрагированных образцах почвы. Повышение их содержания в экстракте анализируемого образца почвы соответствует снижению их содержания в остатке экстрагированного образца почвы. Комбинированная экстракция слабыми растворами этих кислот и щелочей приводит к обогащению почвы нитратами и хлорсодержащими соединениями нерадиоактивных металлов.

\section{ВИВЧЕННЯ ПРОЦЕСІВ ОЧИЩЕННЯ ЗРАЗКІВ ГРУНТУ, ЯКІ ЗАБРУДНЕНІ НІТРАТОМ УРАНІЛУ}

\section{Х.Ф. Маммадов, Х.Н. Ширалієва, С.І. Мехтієв, У.С. Алієва-Джаббарли, Є.І. Кулієв, Н.А. Мирзаєв,} А.Г. Гусєйнова

Комбіноване екстрагування забрудненого нітратом уранілу грунту слабкими розчинами азотної і соляної кислоти, їдкого натрію і подальше промивання залишків грунту дистильованою водою призводять до більше десятиразового зниження вмісту ізотопів урану $\left(\mathrm{U}^{238}, \mathrm{U}^{235}, \mathrm{U}^{234} \mathrm{i} \mathrm{U}^{236}\right)$ у грунті. При цьому спостерігається зниження також вмісту природних радіонуклідів $\left(\mathrm{Na}^{22}, \mathrm{~K}^{40}, \mathrm{Zn}^{65}, \mathrm{Sn}^{113}, \mathrm{Sn}^{126}\right)$ в екстрагованих зразках грунту. Підвищення їх вмісту в екстракті аналізованого зразка грунту відповідає зниженню їх вмісту в залишку екстрагованого зразка грунту. Комбінована екстракція слабкими розчинами цих кислот і лугів призводить до збагачення грунту нітратами і хлорвмісними з'єднаннями нерадіоактивних металів. 